\title{
Biblical pragmatism in the pandemic outbreak of Numbers 25:1-18: Towards an African paradigm
}

\section{Author: \\ Sampson S. Ndoga ${ }^{1}$ (D) \\ Affiliation: \\ ${ }^{1}$ Department of Old \\ Testament and Hebrew Scriptures, Faculty of \\ Theology and Religion, University of Pretoria, \\ Pretoria, South Africa}

Research Project Registration: Project Leader: D.J. Human (1) Project Number: 2364743

\section{Description:}

This research is part of the research project, 'Old Testament and Actuality Themes and Religion', directed by Prof. Dr Dirk Human, Old Testament and Hebrew Scriptures, Faculty of Theology and Religion, University of Pretoria

\section{Corresponding author:} Sampson Ndoga, samndoga@gmail.com

\section{Dates:}

Received: 29 Oct. 2020 Accepted: 12 May 2021 Published: 12 July 2021

How to cite this article: Ndoga, S.S., 2021, 'Biblical pragmatism in the pandemic outbreak of Numbers 25:1-18: Towards an African paradigm', HTS Teologiese Studies/Theological Studies 77(4), a6375. https://doi.org/ 10.4102/hts.v77i4.6375

\section{Copyright:}

(C) 2021. The Authors. Licensee: AOSIS. This work is licensed under the Creative Commons Attribution License.

\section{Read online:}

Scan this QR
code with your
smart phone or
mobile device
to read online.

Numbers 25 presents a human crisis requiring swift leadership interventions to curb the plague. Leadership failure plays out on a number of levels before decisive and resolute interventions are taken. This passage shows a human-created crisis that somewhat parallels the coronavirus disease 2019 (COVID-19) outbreak and offers reflective pragmatic approaches taken to ensure immediate arresting of the pandemic and perhaps future curbing of a similar instigation.

Contribution: Africa has always been known to respond rather belatedly to crises that cost human lives and also for waiting for solutions to come from elsewhere. How do we change that paradigm going forward and what does it mean for the analysis of biblical texts? African hermeneutical readings that take contextual issues rather seriously are utilised in this study.

Keywords: leadership; crisis; pandemic; outbreaks; cultic; COVID-19; Numbers 25.

\section{Introduction}

Plagues, pestilences and pandemics are all historical phenomena mostly exacerbated by manmade negligence. Numbers 25:1-18 provides illustrative biblical material showing human and leadership challenges in times of crisis. Various levels of irresponsibility play out in this passage, which can parallel contemporary experiences. Africa's leadership (un)preparedness for managing pandemics always comes to the fore as seen from recent responses to Ebola and cholera outbreaks. ${ }^{1}$ The absence of rapid means of communication strategies and/or containment measures has always hampered effective response. All of these measures have exposed leadership shortcomings, particularly the tendency to seek solutions from elsewhere towards containment of crises as Bedford et al. (2019), Sambala et al. (2018) and Fraundorfer (2016) revealed. The outbreak of the coronavirus disease 2019 (COVID-19) crisis has raised those historical questions of leadership preparedness to respond adequately given the predicted sense of widespread impact (see Maffioli 2020; Mensah et al. 2020; Wadoum \& Clarke 2020). Whilst there have been cholera and Ebola outbreaks elsewhere on the continent, these have not been experienced in South Africa where I am currently situated, implying that the HIV and AIDS epidemic remains the recent challenge. With specific reference to HIV and AIDS, the controversial 'academic' handling of this crisis under the presidency of $\mathrm{Mr}$ Thabo Mbeki raised leadership questions on the denialism characteristic of the stance at that time. ${ }^{2}$ A lot has improved with the regime (leadership) change; however, the COVID-19 crisis will be the litmus test for the Ramaphosa presidency to showcase original efficient and effective response. ${ }^{3}$

Thinking about the COVID-19 calamity, other documented outbreaks throughout history come to the fore from the 3000 BC circa pandemic that wiped out a prehistoric village in China to the 2015 Zika virus affecting South America and Central America to date. ${ }^{4}$ Certainly the Spanish Flu of

1.A number of studies raise the concern of preparedness for facing crises or various pandemics, such as Preacely and Nsubuga (2011) (cf. Sambala et al. 2018; Steelfisher 2015) on influenza, Fraundorfer (2016) on Ebola and Wadoum and Clarke (2020) on COVID-19.

2.President Thabo Mbeki argued that a virus cannot cause a syndrome, which is a collection of diseases. A Harvard study published that between 2000 and 2005 more than 330000 lives or approximately 2.2 million person's years of life were lost because a feasible and timely antiretroviral (ARV) treatment programme was not implemented in South Africa. In all, 35000 babies were born with human immunodeficiency virus (HIV), resulting in 1.6 million person-years lost by not implementing a mother-to-child transmission prophylaxis programme using nevirapine. The total lost benefits of antiretrovirals are at least 3.8 million person-years for the period 2000-2005 (see Chigwedere et al. 2008:410). South Africa now has the largest ARV treatment programme in the world.

3.Encouragingly, Karim's (2020) report shows methodical and precision of the eight-stage intervention in the South African government's response to the COVID-19 crisis with telling results.

4. Most pandemics that are documented historically have been respiratory related from the $430 \mathrm{BC}$ Athens disease, 165-180 AD Antonine Most pandemics that are documented historically have been respiratory related from the $430 \mathrm{BC}$ Athens disease, $165-180$ AD Antonine plague, the 250 Cyprian plague, 541 Justinian Plague, the 1350 Black death, 1492 Columbian Exchange, the Great London plague of
1665 , the 1855 Third plague, the Russian flu of 1889, the deadly Spanish flu of 1918, the Asian flu of 1957, the 2003 SARS and 2009 1665, the 1855 Third plague, the Russian flu of 1889 , the deadly Spanish flu of 1918, the Asian flu of 1957, the 2003 SARS and 2009
H1N1 pandemic. Whilst there have been other pandemics in between, the respiratory related ones seem to be the most frequent in recent times. Klein (2020) predicted a similar pattern heading into the future as confirmed by the studies of Steelfisher et al. (2015), Walker (2018) and Sambala et al. (2018). 
1918-1919 regarded as the most devastating pandemic of the previous century affecting 500 million people, a third of the world's population at that time, saw the demise of an estimated 50 million people (see Schwartz 2018). And similar respiratory pandemics have been periodic in recent times, with the 2009-2010 swine flu (H1N1) being the worst suggests the true extent of deaths could have been as high as $570000 .{ }^{5}$ These developments have necessitated interdisciplinary interests in approaching challenges as demonstrated in Hart's (2016) study that has utilised the ancient Hebrew text for modern day disease diagnostics, just like biblical scholars delved into the HIV/AIDS pandemic studies. ${ }^{6}$ This article will consider leadership and biblical approaches in responding to the COVID-19 crisis by extrapolating insights from a key biblical text, Numbers 25, towards reflective considerations.

In reading Numbers 25, African hermeneutical approaches are deliberately courted in view of the embedded leaning towards finding meaning of biblical texts to existential challenges. The text and context, revelation and situation are perennially in conversation where interpretation of texts is intended to challenge real-life situations. The concern for integrating real-life situations in reading biblical texts became synonymous with African theologians upon discovering the limitations of western modes of biblical interpretation. Ukpong (1995) represented some of the early African theologians routing for an approach to biblical texts that would make sense to Africans when he wrote:

African biblical scholars have, until recently, not been able to salvage the situation. Trained as they have been in the tradition of western biblical scholarship, they read the bible through an interpretive grid developed in the western culture, and then seek to apply the result in their own contexts. One outcome of this has been a visible gap between this academic reading of the bible and the needs of ordinary African Christians. Another outcome has been the fact that in many ways African social and cultural concerns are not reflected in such reading. (p. 4)

By the turn of the century, his call for inculturation and hermeneutics had found fertile ground demonstrable, for example, by Folarin's (2008) reading of the parable of the talents in the African context, which he calls an inculturation

\footnotetext{
5.Interestingly, in May 2018, medical reports were already predicting that the next pandemic would likely be a resiratory based virus although the science for such pandemic would likely be a res prognostication is uncar (see Molly walk's writs://www. medpagetoday.com/infectiousdisease/publichealth/72867). This has obviously fuelled the conspiracy theories of deliberate unleashing of lab-engineered virus. According to the New Scientist write-up by Alice Klein, '[t]here are estimated to be up to 800,000 viruses in animals that have the potential to infect humans. But identifying them is a task of Sisyphean proportions. One of the main programmes that seeks to detect novel viruses, PREDICT, run by the United States Agency for International Development, spent 10 years and more than $\$ 200$ million searching in 30 countries and managed to uncover just 931 novel viruses in wild animals, livestock and humans. Some of these are deemed potential threats to humans, including novel strains of Ebola and variants of the SARS and MERS coronaviruses. However, the project didn't detect the COVID-19 virus before it spilled over into humans. Funding for PREDICT has been extended to September to support response humans. Funding for PREDICT has been extended to septen to the current outbreak, but its primary mission ended in March.' https://www. newscientist.com/article/2246259-this-wont-be-the-last-pandemic-where-will-the-
}

6.See Mubangizi (2018) that reflected multidisciplinary conception in approaching theological response to the HIV/AIDS pandemic which represents one of severa such studies. hermeneutic that utilises social-cultural context and worldview as the subject of interpretation. An outsider's endorsement of this approach is articulated in Wuench's (2019:27-31) reflections on the distinctions of African theology that are worth highlighting when he notes these cardinal points:

- Integrating real life and theology, which means striving to be rooted in everyday life.

- Integrating real life means integrating non-academics implying everyone has a right to participate.

- Integrating real life leads to a less strict and extreme theology bridging the distance between 'belief in' towards 'participating in'.

- Integrating real life means integrating the theologian himself or herself by embracing all of life experiences and situations of the reader.

- Integrating real life means dialogue between culture and the Bible.

Wuench's summation is in effect the fruit of an exercise undertaken by African theologians in responding to the question on what the task of doing theology in Africa entails, which Dickson et al. (1985) anecdote:

Accepted definitions of theology emphasized three components: an experience of encounter with God in Jesus Christ; reflection on this experience in terms of the human situation; and expression of that reflection in the people's language, this conceived broadly to include mother tongue, patterns of preaching, art, music, dance and other expressions. It was pointed out that when theology becomes explicit, that is simply the articulation of the experiences and perceptions of God already implicit in the Christian praxis of the People of God and, more generally, the human family. (p. 93)

Perhaps another voice on African hermeneutics is that of Draper's (2015) in which he proposes a tripolar model as a theoretical framework for reading the Bible in Africa entailing distantiation, contextualisation and appropriation. Because of the embeddedness of African contextual hermeneutics to the reader's situation, Draper's emphasis on distantiation is an important consideration when he suggests:

The preference for distantiation also is a consequence of my own experience in the apartheid struggle of trying to resist hegemonic readings by, perhaps, exaggerating the text's difference from ourselves and our context and refusing to accept too easily that I knew what it meant, so as to allow fresh insights and to allow the voice of the text to speak over the hubbub of our own voices.

Distantiation derives from viewing the text as normative, thus actively constructing a world the reader can enter and live in imaginatively so as to be transformed by the experience of another (Draper 2015:11). Contextualisation as the starting point of textual analysis emphasises:

[T] his concession [which] requires that the South African reader should start with contextualisation, with the acknowledgement of the pre-understanding she or he brings to the text, the reason for reading it, the questions being addressed. (pp. 14-15) 
Then appropriation considers the conversation that ensues between the context of the text and the context of the reader, which enables the production of meaning and hence transformative praxis (Draper 2015:13). Draper's framework that has been deployed through reading communities for greater interpretive synergies, represents what other scholars perhaps articulate in their own conception as Nyiawung (2013:1) surmised that African hermeneutical perspective 'is a blend between the historical data of the text [distantiation], its sociological concerns [contextualisation] and the contextual realities of the subject of exegesis [appropriation]'. The reading of Numbers 25 in this study foregrounds these strategies to enable the conversation between the text and our context.

\section{Biblical plagues and leadership challenges}

The medical side of biblical plagues is coming to light through seminal studies by scholars such as Hart (2016) who crossed the disciplinary lines to glean insights from the ancient biblical text to inform current medical studies. For example, whilst the plague in Numbers 25 is unnamed just like several others (Gn 12:17; Ex 7:1-12:30; Lv 26:14-16, 21; 19:18; Nm 11:31-34; 14:10-20, 36-38; 16:41-50; Dt 28:15-24, 59-62; 29:22; 32:33-35; 2 Sm 24:15), Hart (2016:74) cited the Berlin physician Hermann Friedberg who declared that the plague of Baal Peor was possibly syphilis based on certain cues from the text. He expands:

The hygienic rules imposed on the Hebrews 'on pain of death' represent an absolutely superior spirit that understands the ultimate significance of public health and the value of medicine indeed when modern physicians such as Hamonic read the Bible and especially the Mosaic law code, not as a religious text, but as a medical guide, that is, what appeared to the masses even many educated individuals as a collection of religious studies and laws or rituals was in fact a hygiene code, an elaborate set of beliefs and practices designed by Moses, in all his genius to keep the Hebrew people physically or eugenically pure and healthy. (p. 77)

By the same token, Numbers 25 from which some medical insights are gained also provide leadership reflections that can be brought to the fore in responding to the COVID-19 crisis. Whilst the Baal Peor episode (Nm 25:1-18) takes place in circumstances geographically and contextually different from ours, the experience which was at a critical juncture in the narrative traditions about early Israel offers indisputable parallels to contemporary situations. Occasioned by the arrival of the Israelites in the Plains of Moab at a place named Abel Shittim (hassitim, 'the Acacias') under the leadership of Moses with Joshua poised to take over after this last stop before Canaan (Nm 33:49), this account exposes gaps in leadership competence perhaps highlighted in previous encounters. Leading to the Baal Peor is a history of chastisements:

- craving for meat (11:1-15)

- election of 70 elders and Joshua's remarks (11:16-30)
- $\quad$ plague during the provision of quail (11:31-35)

- dissension of Aaron and Miriam (12:1-10)

- the conflicting report of the spies (13:1-33)

- refusal to enter the Promised Land (14:1-10)

- rejection of the unfaithful generation (14:11-25)

- futile attempt to enter the Promised Land by force (14:39-45)

- Korah Rebellion (16:1-40)

- reactions of the Korah judgement (16:41-50)

- Moses' costly error at Meribah (20:1-13)

- death of Aaron (20:22-29)

- fiery serpents sent because of complaints (21:4-9).

The list of issues is debilitating especially from this location on the threshold of the Promised Land from where the spies were dispatched (Jos 2:1; cf. Nm 13:2) and the crossing of the Jordan undertaken (Jos 3:1). With that carnage of leadership issues, which forfeited Miriam, Aaron and Moses' entrance into the Promised Land, the Baal Peor account marked the final disciplining of the unfaithful generation out of Egypt, 'following successive chastisements and purges of which the last is described in this episode' (Blenkinsopp 2012:86).

\section{Leadership demises in Numbers 25}

Numbers 31:15-16 reveals that the sexual promiscuity of men of Israel with the Moabite women recorded in Numbers 25:1-18 was a deliberate strategy of Balaam the son of Beor to incite them against the Lord. ${ }^{7}$ This insight sheds some light on the redactional placement of the Balaam narratives of Numbers 22-24 before Numbers 25 to complete the first half of the narrative on the threshold of the Promise Land. These developments have a bearing on the second half of the book of Numbers commencing with a census (in Nm 26:1-65; cf. Nm 1:1-54), which marks the beginning of the new generation poised to enter the Promised Land. The plague that takes place here and later referenced as a paradigm of apostacy (Nm 25:4; 26:1; cf. Dt 4:1-4; Jos 22:15-20; Ps 106:28-31; Hs 9:10) marks, according to Pettit (2018:461), the last stop of the unfaithful generation stripped of the privilege of entering the Promised Land in Numbers 14:26-38.

The 'counsel of Balaam' (Nm 31:16; cf. Nm 24:14; 2 Pt 2:15 and Rv 2:14) which Moses was seemingly aware of presents perhaps the first attribution of negligence on the part of Israel in falling for this set up. Reading the narrative in Numbers 25:1, the statement that the (

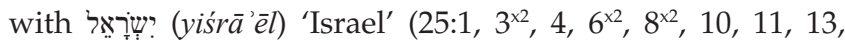
14) conjures the admirable unrelenting quality of Jacob in seeking divine blessing as a mandatory characteristic of his descendants. Whilst Israel, which means 'he contends with God', was the name Jacob was given by the Lord (Gn $32: 29 ; 35: 10)$ it became the designation for all his descendants (Gn 34:7; 49:7; Ex 18:25; 1 Sm 13:19; 2 Ki 6:23; Ezk 27:17)

7.According to Cohen (2013:14) on the role of Balaam the heathen prophet "the Midrash attributes it to the advice given by the heathen prophet Balaam: frustrated by his vain attempts to curse the Irraelites, by his vain attempts to curse the lsraelites, Balaam told the Moabite king who had hired him that the only way to overcome the lsraelites was to estrange them from their God by luring them into immorality. Balak accordingly set up the market stalls near the Israelite camp, with beautiful girls who enticed the men who came to buy their wares'. 
particularising the covenant-election and obligations (Ex 19:5; Is 41:8; Ezk 20:5). On the contrary, whilst situated at Shittim, sometimes known by the literal translation Acacia trees ${ }^{8}$ or later by its fuller name Abel-shittim (33:49; cf. Jos 2:1; 3:1; Mi 6:5), which scholars identify as Tell el-Kefrein, 7 miles (mi) east of the Jordan and 6 mi north of the dead sea (Budd 1984:279; Harrison 1990:335; Noth 1968:196), on the fringes of the Promised Land Israelite men naively prostituted themselves with Moabite women. ${ }^{9}$ The use of the hif îl stem in (hălăl) indicates the profanity from treating with contempt known guidelines (Ex 34:15-16). The verb זָנָּ (zāna $(h))$ 'harlotry' as a figurative extension of sexual promiscuity here specifically refers to improper intercourse with foreign women identified as daughters of Moab where speaks generically of any woman of marriageable age (Gn 30:13; Jdg 12:9b) (see Swanson 1997), but in this case women worshipping a foreign god (Jos 23:11-13; Jdg 3:5-7; 1 Ki 11:2; Ml 2:11) to emphasise the incompatibility (Holladay \& Köhler 2000:51). Cole (2000) pointed out that the NIV phraseology, ' $[t]$ he men began to indulge in sexual immorality', translates the more emphatically worded Hebrew text, which literally reads, ' $[t]$ hen they committed profanity by fornicating' with Moabite women residing in the area.

The second indication of negligence seems to be categorised as leadership on a number of levels. At a corporate level, primarily from the warning that had been issued in Exodus and the fact that it seemed to be known intelligence that the Moabite women were a setup no one was exempt from taking ownership for this demise. Whilst Harrison (1990:334) stated that it is not easy to say why the Israelites submitted to the temptation instigated by Balaam, it becomes obvious that there is a serious breach when the Moabite women invite Israelite men as guests to participate in their religious ceremonies. The verb קָרָ $\left(q \bar{a} r \bar{a}\left({ }^{\prime}\right)\right)$ 'summon' has derivatives that can mean to offer customary hospitality (1 Sm 9:13, 22; 2 Sm 15:11; 1 Ki 1:41, 49; Est 5:12; Pr 9:18; Zph 1:7) but in this case a veiled plot beyond the illicit intercourse into cultic prostitution. At this point of such blatancy and with the disastrous and parallel developments of Exodus 32 of the golden calf demise, some intervening action should have been imposed. ${ }^{10}$ This was neither an innocent invitation nor simple sexual indulgence with Moabite women but full participation in their divinities, which is metaphorically connoted in the cultic language of acting unfaithfully (Ex 34:16; 2 Chr 21:11, 13; Hs 4:10, 18, 18; 5:3) and explicitly stated as being 'yoked' (șẫmăd) pertaining to being in an association based on common beliefs or actions (Nm 25:3, 5; Ps 106:28) as a figurative extension of yoking or strapping two animals together, thus adopting foreign worship (Brown et al. 1977:855).

8.The wood used in the construction of the Tabernacle in Exodus 25:13; 38:1, 6 .

9.Although Josephus connected the place with Abila from the proper name Abel east of the Jordan which would be Tell el-Hamman (see Ashley 1993:514), the location remains within the same vicinity of the plains of Moab.

10.Grossman (2007:58) showed the parallels between the golden calf incident of Exodus 32 and the demise in Numbers 25 where both show the people's indulgence (Ex 32:6; Nm 25:1-2), the Lord's anger is aroused (Ex 32:10; Nm 25:3), lives are lost (Ex 32:28; Nm 25:9), Levites intervene (Ex 32:28; Nm 25:7-8) and are rewarded (Ex 32:29; Nm 25:10-13).
The full participation of Israelite men in Moabite worship is represented, firstly, in their participation in Moabite Sacrifice זְּב (zěbăh) (Swanson 1997), an offering killed and presented as an act of worship, expiation or propitiation to a deity (Gn 31:54). This could never be passive participation as confirmed by the fact that ancient sacrifices included the essential rite of (אָָָ 'âkăl) 'eating' the flesh of the animal (Gesenius \& Tregelles 2003:238). Another give-away to their compromising is hinted by their 'bowing' חָזָ $(h \bar{a} w \bar{a}(h))$, thus taking a stance of respect or honour (Gn 43:28), an associative meaning of allegiance to that deity (Ex 4:31) (Gesenius \& Tregelles 2003:813). The full-blown spiritual adultery rightly categorised by Schellenberg and Geddert (2005:175) as the story of this narrative completes the complete yoking of the Israelite men from Yahweh to Baal of Peor (Nm 23:28; 31:16; Jos 22:17), a high point in Moab in which Baal was worshiped, possibly near Mt. Nebo (Dt 4:3; Hs 9:10) perhaps alongside other divinities such as Chemosh (cf. 1 Ki 11:7; 2 Ki 23:13) because the concept אֶלהים ('élōhîm) is in the plural construct. This construct correctly translates to gods and implicates other Baals, hence Baal Perazim (2 Sm 5:20; 1 Chr 14:11), Baal-hermon (Jdg 3:3) or Baal-hazor (2 Sm 13:23) as the epitome of spiritual fornication (Gn 38:24; Lv 21:9; Dt 22:21; Hs 4:13-14; Am 7:17; cf. Is 57:3; Jer 2:20; Ezk 16:15; Hs $2: 7)$. It is this flagrantly obstinate mutiny against Yahweh that arouses the anger of the Lord whose jealousy is iterated based on the cultic exclusivity clearly spelt out in Exodus 20:3. The verb חָרָז $(h \bar{a} r \bar{a}(h))$ as an expression of having strong feelings of displeasure with consequential outcomes (Ex $22: 23 ; 32: 10$, 19; Is $41: 11 ; 45: 24$; Jer $12: 5 ; 22: 15)$ qualifies the noun as an area that can change colour when blood rushes to it whilst one is angry (Gn 27:45) (Swanson 1997). The blatancy of the rebellion is so widespread that the collective name

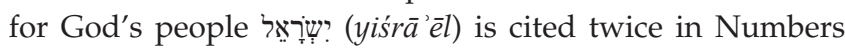
$25: 3$, revealing the contradistinction between their identity and their indulgence. From reading between the lines, it is plausible that precisely at this point of the instigation of Yahweh's anger that the resultant plague mentioned in Numbers 25:9 actually commenced (cf. Nm 16:46-50; Ps 106:29). Rekindling Yahweh's anger (see Gn 30:2; 39:19: 44:18; Ex 4:14; 22:24; 32:19,22; Nm 11:1, 10,33; 12:9; 22:22,27; 24:10) by breaching the emphatic statement of exclusivity of his worship alone would have been in their recent memory with the golden calf incident and its aftermath (Ex 32:1-35). This recurrence instigated by Moabite women should not have been entertained at any cost.

A closer analysis of the golden calf account reveals Moses blaming leadership failure on Aaron's part for the people's lack of restraint (Ex 32:25, 35). The obvious question to ask here from a similar perspective with the accountability structures that had been established is (cf. Ex 18:25; Nm 11:16-30), 'why was there a lack of restraint?' Unsurprisingly, the divine response to the provocation is telling when he asks Moses (Nm 25:4) to impale all the ראש (rō(')̌s) 'leaders' which Dozeman (1998:195) surmises that 'the use of the term suggests the divine judgement is not limited to the guilty but 
falls indiscriminately on all leaders' (cf. Steinberg 2007:119). The terms envisage heads of the divisions of the tribes (Nm 10:4) or even as Holladay and Köhler (2000:329) correctly identified as chiefs; the selected individual sent as spies because of the leadership pedigree ( $\mathrm{Nm} \mathrm{13:3);} \mathrm{alongside} \mathrm{the}$

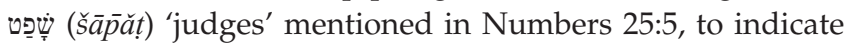
a well-organised leadership structure for managing such crises. Somehow in the midst of this rebellion, the centre fails to hold as this becomes the final straw for the unfaithful generation where the ringleaders are to be publicly impaled.

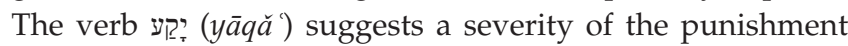
with connotation of twisting, wrenching or spraining the body with the view to dislocating it through pressure (Holladay \& Köhler 2000:142). The idea of public execution and/or non-burial of corpses mooted here from the hint of being hung in the sun before the Lord in order for his anger to dissipate (Nm 25:4) infers the indignity of the offenders as stated elsewhere (2 Sm 21:12-14; Ec 6:3; Is 34:3; Jer 16:4; 25:33). Cole (2000) espoused that such public exposures were reserved for the most heinous crimes in ancient Israel and Mesopotamia. The tribal leaders, as Harrison (1990:336) asserted, should have been preventing the people from participating in the sexual promiscuity with the Moabite women and the cultic harlotry.

In keeping with the leadership negligence, the instruction by Moses in asking the judges to kill every one of their men who were joined to Baal of Peor, is seen by most scholars as failure to heed divine instructions (Grossman 2007:58; Olson 1996:153; Pettit 2018:461). ${ }^{11}$ In lieu of enlightening details in the narrative, it is plausible to assume that the divine instructions were not carried out, ${ }^{12}$ whilst in the interim a plague had broken out and was causing heavy losses of life. In the context of such taxing developments, Moses' oversight is quite perplexing about his incapacitation, as Pettit (2018:461) remarked, especially having been given a divine directive already. What rather transpires is the daring and bold move by Zimri of presenting a Midianite woman to his brethren, actions that are totally out of sync with the current tempo of the gathered repentant, remorseful remnant by the Tabernacle. Zimri orchestrates his provocation in the sight of Moses who has his hands full with the rampaging plague (25:6). The shift in the text from Moabite to Midiate is culturally normal as both groups are known to have lived side by side (Boniface-Malle 2006:196; Crane 2004:717; Noordtzij 1983:238) although some scholars regard this as two separate stories being juxtaposed for redactional expediency (see Albertz 2013:222-223; Kim 2010:260-264; Monroe

11.Steinberg (2007:123) saw Moses' leadership failure as a change in policy from what God had actually instructed. He registers that 'paradoxically, although Mose is involved in verse 6 onwards, he is passive and very different from the Moses that just took the initiative to change God's words in verse 5. The Moses, or the leader, presented in verse 6 is a passive witness, possibly stunned into silence. Hence, another question is: Why? Moses does nothing and says nothing about what Phinehas did. He does not step in and intervene by stopping him helping him praising him or does not step in and intervene by stopping him, helping him demanded, was it a reminder to Moses that he changed God's words? If so, did demanded, was it a reminder to Moses that he changed God's words

12.Monroe (2012:213) affirmed that 'nothing is made of the disjuncture between God's command to Moses and Moses' instructions to the people and, in fact, there is no indication in the narrative that either God's command or Moses' is fulfilled'.
2012:213; Organ 2001:203). ${ }^{13}$ Perhaps another possibility of Moses' incapacitation emanates from his own personal reality through his marriage to Zipporah (Ex 2:21) who herself had caused some tensions between Moses and his siblings (Nm 12:1-2). ${ }^{14}$ If this scenario is playing at the back of his mind, Moses would understandably be traumatised as Crane (2004) painted the picture of Zimri, who:

$[R]$ ather than sneaking his foreign pleasure into camp (cf. Josh 7:20-22), [he] blatantly parades with her in full view of Moses and the assembled Israelites, who are weeping at the court sanctuary. (p. 718$)^{15}$

Turning our attention to Zimri for a moment, the narrative later issues a telling biographical insight - the son of Salu, a

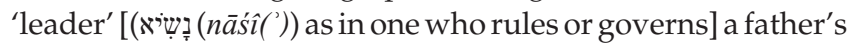
house amongst the Simeonites. Coming from a prominent family, Zimri should have taken precautionary measures, and his own family (Nָ 'ạh) mentioned in 25:6 as in blood relative or people from the same offspring, clan or fellow kinsmen, were ideally positioned to assist with sanity. Even if the occasion, as some have argued, was an arranged marriage (Pettit 2018:461; Rees 2012:17), the timing was treasonous and the unconcealed consummation a provocation. It turns out that the Midianite woman herself, named Cozbi, hails out of a prominent family as the daughter of Zur, the head of the people of a father's house in Midian. Pettit (2018:461) commented that Zimri's marriage to Cozbi was therefore a strategic alliance between two prominent families, the head of an ancestral house of Israel and the daughter of a head of a Midianite ancestral house. Schellenberg and Geddert (2005:175) suggested that Zimri's action was seemingly designed as part of a plot to draw Israel into the Midianite religious cult by provoking those gathered at the Tent of meeting. The conceivability of this move rests partly on the interpretation of the rare noun $(q u \grave{u} b b \bar{a}(h))$ used only here (25:8) referring to the tent into which Zimri and Cozbi were followed by Phinehas. This tent is seen by some as an inner vaulted room utilised as women's quarters (Ashley 1993:520; Organ 2001:208) or a brothel in later rabbinic literature (Barry et al. 2016) and others see a more pointed reference to a portable shrine (Cole 2000; Organ 2001:208). If that is the case, the location of this tent is singularly incongruous not only for the act that ensues therein but as a challenge to the

13.Fleurant (2011:286) treated the account from two possibilities: (1) Numbers 25 is made up of two different stories that were merged into one narrative and (2) this was done by a late redactor who solidified the juncture with a literary layer of his own, in order to whitewash the prophetic figure of Moses. He proposes that the first tendency focuses exclusively on the synchronic reading of Numbers 25 . The second tendency, in contrast to the first one, is to use historical criticism to find and verses $6-18$ to $P$. Whilst the absence of a consensus on the distribution of verses raises doubts about the reliability of the method, general agreement on verses raises doubts about the reliability
certain key verses provides credibility.

14.Blenkinsopp (2012) raised the important question of the surprising disregard throughout the history of interpretation of the Baal Peor episode to another sraelite-Midianite marriage, that of Moses to Zipporah. 'The question now arises: Why did the marriage of Moses to a Midianite woman pass without comment whilst Zimri's marriage to Cozbi elicited homicidal rage not only folly vindicated post factum but richly rewarded? Was this another aspect of the unique status of Moses, reaffirmed in response to Miriam's complaint about his marriage to the issa kûsit (Nm 12:1)?' Moses' marriage to Zipporah was never condemned despite kusit (Nm 12:1)? 'Moses marriage to Zipporah was never condemned despite obligations had not yet been signed so clearly it was not in view during this crisis.

15.Lutzky (1997:547) revealed a play on Kozbi's name with the root kzb having theological ramifications. Its basic meaning is ontological rather than ethical, that is, (objectively) untrustworthy, false, worthless (like a delusion), rendered $\Psi \varepsilon u \dot{\delta} \delta \circ$ in Greek. In the Hebrew Bible, 'falseness' is the basic accusation against idols. 
Tabernacle. That is simply epic even if the story represents redactional stitching of the intention, which serves well to arouse the fierce anger of the Lord.

To recap the observations here, on a number of levels, during a crisis, Israel is found wanting. Firstly, the people in this individual and corporate capacity as God's people fall for a trap that they could have averted had they simply learnt from prior experiences in many ways parallel to the current challenge. Secondly, their designated leaders also failed to dislodge or dissuade them from engaging with Moabite women, who had the propensity of regressing into full-blown rebellion against Yahweh. Thirdly, Moses, although he seemingly was springing into action as per divine instruction, is reduced to inaction at the onset of the blatancy of Zimri and his Midianite woman. Fourthly, Zimri himself hails out of a leading family who fails to sensitise him to the gravity of his blatant debauchery or at least tone down in his own right his intentions in the constraints of the costly plague. Against this backdrop of seismic leadership failures, Phinehas' resoluteness is daring, decisive and distinguished.

\section{Resolute leadership in Numbers $\mathbf{2 5}$}

Phinehas, whom we are first introduced to as the last name in Aaron and Moses' genealogy in Exodus 6:14-27, has an Egyptian-influenced name which means 'dark skinned' (Budd 1984:280; Noordtzij 1983:241). The subsequent prominent appearance of his name relates to the heroic act carried out in Numbers 25:7-8 that causes Yahweh's fierce anger to be appeased and for the plague that had arisen to be quelled. In what seems like an individual initiative, Phinehas' response is, firstly, daring on seeing Zimri and Cozbi going into a tent, perhaps for sexual pleasure, where he picks up a javelin with which in one sure strike, he exterminates the offending parties. At this stage of executing this hideous act, he had no guarantee of the outcome other than the possibility of a double murder. Cohen (2013:15) cited the Midrash that supplies details on the impasse not found in the narrative that could have motivated Phinehas' stance:

The Midrash states that Zimri dragged Cozbi by the hair in front of Moses and the elders, and challenged Moses, saying, 'Tell me, son of Amram, is this woman permitted to me or not?' When Moses replied, 'She is forbidden', Zimri gave an insolent riposte: 'You call yourself a faithful interpreter of God's law. How can she be forbidden to me when you yourself, Moses, married a Midianite. Furthermore, this one is the daughter of a king, whereas your wife, Zipporah, is the daughter of an idolatrous priest!' Moses broke down in tears, unable to answer the personal insult hurled at him or to recollect the punishment Zimri deserved for his outrageous behaviour. ${ }^{16}$

16.If the Midrash details are correct, then Schellenberg and Geddert's (2005:175) view stands that the context makes clear, Zimri's action was designed as part of a plot to draw Isral into the Midianite religious cult. They add that 'this act plot to draw Israel into the midianite religious cult. They add that 'this act of apostasy was not a covert affair. It was designed to provoke those who had gathered at the tent of meeting to mourn Israel's deteriorating spiritual condition and the plague that had come as a consequence of it'.
Whilst we have no way of authenticating the additional details that the Midrash supplies, Phinehas' response is nevertheless quite pointed. Without waiting for a second invitation, Phinehas followed the two into their tent to slay them. ${ }^{17}$ Something here had had the final straw on him.

Secondly, Phinehas' response was decisive in that his initiative in actuality fulfils the divine instruction given in Numbers 25:4. The divine instruction zeroed in on the 'leaders' (ראש (rōš)) as the offenders to be executed publicly in order for the fierce anger of the Lord to dissipate. ${ }^{18}$ Zimri's father is described in Numbers 25:14 as chief or even a chief leader as in one in charge of other leaders (see Nm 3:32). This situated both Zimri and his father high up on the leadership ladder as the title was also used of kings (1 Ki 11:34). Logically, if the execution of the leaders who were responsible for instigating divine anger would resolve it, then Phinehas' heroic act, as Grossman (2007:58) observed, in the slaying of Zimri a prince of the tribe of Simeon fulfils God's expressed will.

In Numbers 25:7 the verb רָָָ $\left(r \bar{a}^{\prime} \bar{a}(h)\right)$ to see is used of the perception of sight to view objects and make judgements based on the discernments (Gn 40:6) (Swanson 1997). It suggests that Phinehas had some appreciation of the developments here where others had failed to be similarly enlightened. Guided insights perhaps informed further by his priestly heritage as the son of Eleazar, the son of Aaron (25:7), he perceived Zimri's actions as the catalyst for the demise of God's people. With a javelin in hand he did not hesitate to follow, as the text particularises, ישָרָאָ the man of Israel (repeated in the same verse) to emphasise the binding covenantal obligations that were being breached. The anonymity of the name of the offender at this stage of the narrative serves to distance Phinehas from personal agenda but simply driven by the blatancy demonstrated here in the middle of a costly plague. The physical impact of thrusting the javelin in one blow from the verb sharp implement (Nm 25:8; Jdg 9:54; 1 Sm 31:4; 1 Ch 10:4; Zch $12: 10 ; 13: 3)$ insinuates a position of intimacy from which this could be achieved. The javelin blow itself is a play on words between its target, the woman's $(q \bar{e} \underline{b} \bar{a}(h))$ 'stomach' and $(q u \breve{s} b b \bar{a}(h))$ a woman's section of the tent as is commonly translated. ${ }^{19}$ In that one decisive act, the

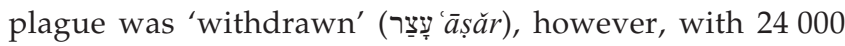
(Nm 25:9) bodies to account for.

17.Sicherman (2008:23) presented another side to the Zimri/Cozbi relationship which is loaded with political connotations. Typical of that time marriages of prominent families were often used as a way to 'contract and consolidate treaties or even to lull an enemy into a false sense of security. Had the relationship of Zimri and Cozbi become a lasting one, Israel's southeastern flank could be open to attack. Phinehas' action destroyed any chance of such an alliance and by the killing of the Midianite princess ensured that Midian and Israel would be at odds'.

18.Steinberg (2005:122) surmised that as actually said in the text, 'the passion and zeal shown by Phinehas served as expiation for God. God orders impalement (v. 4), and it could be the actual impalement of the couple with Phinehas' weapon (a sort of sacrifice) that served as expiation'.

19.Lutzky (1997:546) contended that the context of 'the affair of Cozbi' may have been cultic, rather than sexual. The words for 'tent' (qubba) and 'belly' (qöbätäh) may actually be one and the same word, meaning 'tent-shrine'. 
Thirdly, Phinehas' initiative was deemed distinguishable based on the divine commendation he attracts ( $\mathrm{Nu}$ 25:10-13). The divine approval of Phinehas attributes three things:

- turning back the Lord's wrath (25:11)

- being zealous with the Lord's zeal (25:11)

- making atonement (25:13).

Turning back the Lord's wrath is encapsulated in the verb ( $\check{s} \hat{u} \underline{b})$, which simulates the making of linear motion back to a point previously departed (Gm 8:9). The concept envisages the returning to normal conditions previously enjoyed before the outbreak of the plague, thus endorsing the resolution that resided in Phinehas' intervention. The arousing of the Lord's anger historically had regrettable outcomes unless a resolute intervention was made (Ex 22:24; 32:10; Nm 11:1-2, $10,33 ; 12: 9 ; 16: 44 ; 22: 22,27)$. Phinehas' precision is highly exceptional.

On being zealous, the verb אָָנָ ( $q \bar{a} n \bar{a}$ ') according to Holladay and Köhler (2000:320) is usually associated with (God's) jealousy or eagerness for the Lord (1 Ki 14:22; 19:10, 14), both senses are implied here. ${ }^{20}$ This describes a disposition of an individual completely sold out to a divine cause and is willing to pay any price for its realisation as Cole (2000) correctly articulates:

The cognate terminology emphasizes the likemindedness of Phinehas with that of Yahweh, since the text reads literally, 'When he acted zealously with my zeal among them' (bĕqan 'ô 'et-qin' ātî bétôkām), followed by a repetition at the end of the verse of the phrase 'my zeal'. (p. 9)

Pertaining to the making of an atonement to 'cover over, to overspread' (Gesenius \& Tregelles 2003:411) describes sufficiency of Phinehas' intervention, which is ironically befitting his priestly office and an endorsement of his personal credentials in a leading role. His name is subsequently mentioned in his priestly office of which his family was designated (Jos 22:13; Jdg 20:28; Ps 106:30). It is for these combined reasons that a 'covenant of peace' (běrît $\hat{\imath}$ šālôm) further explicated as (běrît kěhūnnat 'ôlām) a 'covenant of an everlasting priesthood' is carved. Barry et al. (2016) indicated in line with 1 Chronicles 9:19-20 that Phinehas was the chief of the sanctuary guards (a position also held by his father; Nm 3:32). Phinehas' father, Eleazar, was the high priest at this time to show the fulfilment of this covenant going forward. Merril (1985) concurred as follows:

This is defined as a lasting priesthood. Such a promise had been made to Aaron and his sons (Ex 29:9) but not specifically at that time to Aaron's grandson Phinehas. This suggests that the office of priest would now be channeled through Phinehas and not any other grandson of Aaron (cf. 1 Chr 6:4-15). (p. 246)

In the final analysis, all of these threefold aspects of turning back the Lord's wrath, being zealous for the Lord and making atonement, are spoken of in relationship with the children of Israel as the subject. The reference to the Israel thrice in the 1st century took both its name and its inspiration from this great Old Testament hero. these verses (10-13) repositions Phinehas' intervention not purely as an initiative whose impact supersedes individual accolades because the survival of the nation was dependent on it. The verb כָלָָה $(k \bar{a} l \bar{a}(h))$ consume is a stark reminder of what was at stake here for it carries connotation of utter destruction, perishing, wasting away or being ruined with specific reference to Israel (Holladay \& Köhler 2000:158). Israel is therefore preserved as the only entity uniquely called of God to franchise His universal purposes as Schellenberg and Geddert (2005) contended:

The unique identity of Israel was preserved by remembering and celebrating God's past acts of deliverance (Exod. 12:1-27; Ps. 106), by organizing life around the covenant stipulations (Ps. 119), by hearing God's Word (Neh. 8:1-12), by longing together for the fulfillment of God's promises (Isa. 51:9-11; Ps. 79), and last but not least, by taking seriously the special calling God had placed on Israel to be a contrast society in the world, a social experiment in which God's justice and shalom were to be visibly present (Exod. 22:21-27; Lev. 23:22; 25:35-38; Deut. 24:10-22; Ps. 82:1-4; Isa. 58). (p. 171)

It is for this reason of Israel's preservation that the Baal Peor account ends with the instructions to צִ (șārăr) harass as in to treat the Midianites an enemy, adversaries, a foe, or be in a state of enmity with a hostile opponent (Nm 10:9; 25:17, 18; 33:55; Es 3:10; Ps 129:1, 2; Is 11:13b) (Swanson 1997). This is followed by a clear instruction to נָכָ $(n \bar{a} \underline{k} \bar{a}(h))$ that is to 'strike, hit, beat' (1 Ki 20:35; Pr 17:10) in extended sense, hit enemy in battle (Gn 14:5), an instruction carried out in Numbers 31 (Holladay \& Köhler 2000:237). This was meant to permanently solve the possibility of future outbreaks.

\section{Conclusions}

The pivotal nature of the events in Numbers 25 is indisputable in assisting with contemporary responses to (dis)similar challenges. Against the backdrop of a history of chastisements recorded in the Book of Numbers, notwithstanding others since the exodus, everything comes to a head in the Baal Peor incident. There are obvious geographical and time disparities between the text and the contemporary context. For example, there is no possibility that the heroic act of Phinehas could be celebrated or endorsed literally given the strict human rights and potential conviction for a double murder. Furthermore, there is also an established covenantal relationship between Yahweh and Israel through which this special community negotiates all aspects of life. In addition, this incident represents a localised challenge that could in some ways be managed from within that community. Given that the COVID-19 challenge is global, and with treatment still unknown, and with the World Health Organization taking the lead in prescribing the various protocols, there is a real sense that African leaders face an even greater challenge from without. However, the Numbers 25 leadership lessons still apply in terms of Phinehas' dispositional initiative in containing the crisis.

Firstly, Phinehas stands in direct contrast to the leadership failure in Moses, the judges and the ringleaders who were 
meant to be impaled for the demise that plagued the children of Israel. What Phinehas demonstrates in the context of the loss of life instigated by the sexual and cultic promiscuity is a pragmatic approach to the challenge. What that will translate to in our COVID-19 context remains indeterminable except for an inference to what could be a catalyst for a similar outcome if it were feasible given the dissimilar causes and circumstances.

Secondly, Phinehas without knowing the outcome and/or impact of his initiative was able to isolate the problem by taking a risk with a self-diagnosed catalyst as opposed to remaining dormant with the weeping congregants at the entrance of the Tabernacle. As sincere as it might have been, lamenting over the outbreak of the pandemic did not deter the high loss of life. The divine instruction had somewhat indicated the impalement of the offenders, thus effectively containing the soiled members. That in itself was intended to be an effective quarantine of the guilty would have shielded the rest of the community from lockdown.

Thirdly, Phinehas' initiative attracted divine accolades because of his dispositional outlook regardless of his positional limitations. As mentioned in the commentary, Phinehas had no known pedigree or records of the daring, decisive and distinguished leadership that he demonstrates during this crisis. In fact, he is the surprise package of this narrative, an unsung hero to say the least. It seems plausible that in times of crisis leadership always seems to emerge from places one least expects it to as would be subsequently experienced during the leadership vacuum in the time of the Judges where characters such as Ehud (3:12-30) and Jael (4:21-24) excel against the odds. Phinehas certainly fits that bill, retaining his unsung hero status where his contribution is barely mentioned in the Old Testament (Ps 106:30).

Fourthly, although Phinehas was able to bring the plague to an end, he could not prevent the unfortunate and unnecessary loss of the 24000 lives that this demise cost. This is partly because of the fact that this incident was a culmination of a culture of rebellion that had remained the Israelite narrative throughout the wilderness experience. Just like particular families or individuals would have paid for their roles in such incidences, the census that ensues indicates the significant reduction of the Simeonites whilst other tribes increased, if figures of the first census in Numbers 1:23 are stacked against those in Numbers 26:14. The accumulative culture of rebellion and irresponsibility does not save one on the day of reckoning.

Fifthly, and perhaps related to the above pointers, Phinehas' leadership intervention was solely for the benefit of the children of Israel. We have already noted the way the text links all aspects of his initiative to the Israelites as the beneficiaries, thereby divorcing his intervention from personal gains.

Lastly, Phinehas' resolute action became a catalyst for futureproofing the possibility of a similar incident ever recurring.
Getting rid of the problem within became emblematic of solving the challenge without. It is not surprising that the narrative closes with instructions to not only consider the Midianites a serious threat but also get rid of them, thus effectively disabling the possibility of any future encounters.

In looking at this passage in conversation with the COVID-19 crisis we are currently facing, which an African hermeneutical approach legitimates, it has been somewhat a fruitful exercise to engage biblical insights into the fray of things with successful outcomes. Embedded in this approach was a genuine attempt at distantiation, which considered the world of the text. References were made not only to the plagues of Numbers 25, but others by way of providing comparative material to work with. Contextualisation was equally important in the reading of the text where the salient medical concerns in Numbers 25 were brought to converse with the COVID-19 crisis. Appropriation allowed for the possibility of implications that can be derived from this reading with the view to suggesting changes necessary should similar challenges arise in the future. In thinking about the integrative aspects of African theology highlighted in this study not only does the approach bring to the fore academics and ordinary people or project the world of the reader, it also facilitates a dialogue between the Bible and culture. In so doing, the robustness of African hermeneutics speaks for itself in providing a multifaceted approach. It is with such approaches that attempt to wrestle with the rich textual phenomenology and demanding contemporary realities in mind that the analysis of ancient texts will command the greatest interdisciplinary interest going forward. In so doing, diverse reading communities will emerge.

\section{Acknowledgements Competing interests}

The author declares that he has no financial or personal relationships that may have inappropriately influenced him in writing this article.

\section{Author's contributions}

S.S.N. is the sole author of this research article.

\section{Ethical considerations}

This article followed all ethical standards for research without direct contact with human or animal subjects.

\section{Funding information}

This research received no specific grant from any funding agency in the public, commercial or not-for-profit sectors.

\section{Data availability}

Data sharing is not applicable to this article as no new data were created or analysed in this study. 


\section{Disclaimer}

The views and opinions expressed in this article are those of the author and do not necessarily reflect the official policy or position of any affiliated agency of the author.

\section{References}

Albertz, R., 2013, 'A Pentateuchal redaction in the Book of Numbers?: The late priestly layers of Num 25-36', Zeitschrift Für Die Alttestamentliche Wissenschaft 125(2), 220-233. https://doi.org/10.1515/zaw-2013-0013

Ashley, T.R., 1993, The Book of Numbers (New International Commentary of the Old Testament), Eerdmans, Grand Rapids, MI.

Barry, J.D., Mangum, D. \& Brown, D.R., 2016, Faith Bible study, Lexham Press, Bellingham.

Bedford, J., Farvas, J., Ihekweazu, C., Kang, G., Koopmans, M. \& Nkengasong, J., 2019 'A new twenty-first century science for effective epidemic response', Nature: International Weekly Journal of Science 575(7781), 130-136. https://doi. org/10.1038/s41586-019-1717-y

Blenkinsopp, J., 2012, 'The Baal Peor episode revisited (Num 25:1-18)', Biblica 93(1), 86-97.

Boniface-Malle, A., 2006, 'Numbers', in T. Adeyemo (ed.), Africa Bible commentary, pp. 419-424, WordAlive Publishers, Nairobi.

Brown, F., Driver, S.R. \& Briggs, C.A., 1977, Enhanced Brown-Driver-Briggs Hebrew and English Lexicon, The Libronix Digital Library System, Peabody, MA.

Budd, P.J., 1984, Numbers (Word Biblical Commentary), Word Books, Waco.

Chigwedere, P., Seage, G.R., Gruskin, S., Lee T.H. \& Essex, M., 2008, 'Estimating the lost benefits of antiretroviral drug use in South Africa', Journal of Acquired Immune Deficiency Syndrome 1(49), 410-415. https://doi.org/10.1097/QAl. 0b013e31818a6cd5

Cohen, J.M., 2013, 'Phinehas, Elijah \& Circumcision', Jewish Bible Quarterly 41(1), $14-18$.

Cole, R.D., 2000, Numbers, Broadman \& Holman Publishers, Nashville, TN

Crane, R., 2004, The NIV application commentary: Leviticus, Numbers, Zondervan, Grand Rapids, MI.

Dickson, K.A., Kalilombe P.A. \& Presler, T., 1985, 'Development of African theologies', Mission Studies 2(1), 93-96.

Dozeman, T., 1998, The new interpreters' Bible Volume II, Abingdon Press, Nashville, TN.

Draper, J.A., 2015, 'African contextual hermeneutics: Readers, reading communities, and their options between text and context', Religion \& Theology 22(1-2), 3-22. https://doi.org/10.1163/15743012-02201005

Fleurant, J., 2011, 'Phinehas Murdered Moses' wife: An analysis of Numbers 25' Journal for the Study of the Old Testament 35(3), 285-294. https://doi. org/10.1177/0309089210386348

Folarin, G.O., 2008, 'The parable of the talents in the African context: An inculturation hermeneutics approach', The Asia Journal of Theology 22(1), 94-106.

Fraundorfer, M., 2016, 'How to confront the threat of Ebola? Arguing for reinforced efforts to promote transnational solidarity', Global Policy 7(3), 340-350. https:// doi.org/10.1111/1758-5899.12306

Gesenius, W. \& Tregelles, S.P. 2003 , Gesenius' Hebrew and Chaldee lexicon to the Old Testament Scriptures, The Libronix Digital Library System, Peabody, MA.

Grossman, J., 2007, 'Divine command and human initiative: A literary view on Numbers 25-31', Biblical Interpretation 15(1), 54-79. https://doi. org/10.1163/156851507X168494

Harrison, R.K., 1990, Numbers (The Wycliffe Exegetical Commentary), Moody Press, Chicago, IL.

Hart, M.B., 2016, "'They dedicated themselves to the abominable idol": Ancient Hebrew sexuality and modern medical diagnosis', Jewish Social Studies 21(3), 72-90. https://doi.org/10.2979/jewisocistud.21.3.03

Holladay, W.L. \& Köhler, L., 2000, A concise Hebrew and Aramaic Lexicon of the Old Testament, Eerdmans, Grand Rapids, MI.

Karim, A.S.S., 2020, 'The South African response to the pandemic', The New England Journal of Medicine 382(24), 95. https://doi.org/10.1056/NEJMc2014960

Kim, Y.H., 2010, 'The finalizing of Num 25,1-5', Zeitschrift Für Die Alttestamentliche Wissenschaft 122(2), 260-264. https://doi.org/10.1515/zaw.2010.019
Klein, A., 2020, This won't be the last pandemic: Where will the next one come from? viewed 20 June 2020, from https://Www.Newscientist.Com/Article/2246259This-Wont-Be-The-Last-Pandemic-Where-Will-The-Next-One-Come-From/.

Lutzky, H., 1997, 'The Name “Cozbi” (Numbers XXV 15, 18)', Vetus Testamentum 47(4), 546-549. https://doi.org/10.1163/1568533972650901

Maffioli, E.M., 2020, 'How is the world responding to the novel coronavirus disease (Covid-19) compared with the 2014 West African Ebola epidemic? The importance of China as a player in the global economy', The American Journal of Tropical Medicine and Hygiene 102(5), 924-925. https://doi.org/10.4269/ajtmh.20-0135

Mensah, D., Asampong, R., Amuna, P., Ayanore, M.A., 2020, 'Covid-19 effects on national health system response to a local epidemic: The case of cerebrospinal meningitis outbreak in Ghana', The Pan African Medical Journal 35(2), 14. https:// doi.org/10.11604/pamj.supp.2020.35.2.23138

Merril, E.H., 1985, 'Numbers' in J.F. Walvoord \& R.B. Zuck (eds.), The Bible knowledge commentary, pp. 218-258, Zondervan, Grand Rapids, MI.

Monroe, L.A.S., 2012, 'Phinehas' zeal and the death of Cozbi: Unearthing a human scapegoat tradition in Numbers 25:1-18', Vetus Testamentum 62(2), 211-231. https://doi.org/10.1163/156853312X629171

Mubangizi, O., 2018, Theological anthropology and the political economy of HIV and AIDS pandemic from an African perspective, Orbis Books, New York, NY.

Noordtzij, A., 1983, Numbers (Bible students' commentary), transl. ed. V.D. Maas, Zondervan, Grand Rapids, MI.

Noth, M., 1968, Numbers (The Old Testament library), The Westminster Press, Philadelphia, PA.

Nyiawung, M.D., 2013, 'Contextualising biblical exegesis: What is the African biblical hermeneutic approach?', HTS Teologiese Studies/Theological Studies 69(1), 1-9. https://doi.org/10.4102/hts.v69i1.2011

Olson, D.T., 1996, Numbers (interpretation), John Knox Press, Louisville, KY.

Organ, B.E., 2001, 'Pursuing Phinehas: A synchronic reading', The Catholic Biblical Quarterly 63(2), 203-218.

Pettit, D.P., 2018, 'Expiating apostasy: Baal Peor, Moses, and intermarriage with a Midianite woman', Journal for the Study of the Old Testament 42(4), 457-468. https://doi.org/10.1177/0309089216692182

Preacely, N. \& Nsubuga, P., 2011, 'Influenza preparedness and response: Involvement of African field epidemiology and laboratory training programs, 2009', The Pan African Medical Journal 10, 11-11. https://doi.org/10.4314/pamj.v10i0.72219

Rees, A., 2012, '[Re]Naming Cozbi: In memoriam, Cozbi, Daughter of Zur', Biblical Interpretation 20(1-2), 16-34. https://doi.org/10.1163/156851512X618588

Sambala, E.Z., Kanyenda, T., Iwu, C.J., Iwu, C.D., Jaca, A. \& Wiysonge, C.S., 2018, 'Pandemic influenza preparedness in the who African region: Are we ready yet?', BMC Infectious Diseases 18(1), 567-567. https://doi.org/10.1186/s12879-0183466-1

Schellenberg, R.S. \& Geddert, T.J., 2005, 'Phinehas and the pharisees: Identity and tolerance in biblical perspective', Direction 34(2), 170-180.

Schwartz, J.L., 2018, 'The Spanish flu, epidemics and the turn to biomedical responses', American Journal of Public Health 108(11), 1455-1458. https://doi.org/10.2105/ AJPH.2018.304581

Sicherman, M., 2008, 'The political side of the Zimri-Cozbi affair', Jewish Bible Quarterly 36(1), 22-24.

Steelfisher, G.K., Blendon, R.J., Kang, M., Ward, J.R., Kahn, E.R., Maddox, K.E.W. et al, 2015, 'Adoption of preventive behaviours in response to the 2009 H1N1 influenza
pandemic: A multiethnic perspective', Influenza and Other Respiratory Viruses pandemic: A multiethnic perspective', Influenza
9(3), 131-142. https://doi.org/10.1111/irv.12306

Steinberg, P., 2007, 'Phinehas: Hero or vigilante?', Jewish Bible Quarterly 35(2), 119-126.

Swanson, J., 1997, Dictionary of Biblical languages with semantic domains: Hebrew (Old Testament), The Libronix Digital Library System, Bellingham.

Ukpong, J.S., 1995, 'Rereading the Bible with African eyes: Inculturation and hermeneutics', Journal of Theology for Southern Africa 15(91), 3-14.

Wadoum, R.E.G. \& Clarke, A., 2020, 'How prepared is Africa to face Covid-19?', The Pan African Medical Journal 35(2), 1. https://doi.org/10.11604/pamj. supp.2020.35.2.22665

Walker, M., 2018, Report: Next pandemic will likely be respiratory-based virus, viewed 20 June 2020, from https://www.medpagetoday.com/infectiousdisease/ publichealth/72867.

Wuench, H.-G., 2019, 'Learning from African theologians and their hermeneutics: Some reflections from a German evangelical theologian', Evangelical Review of Theology 43(1), 26-39. 